\title{
ANALISIS SINYAL SEISMIK UNTUK MENGETAHUI PROSES INTERNAL GUNUNG IJEN JAWA TIMUR
}

\author{
Oleh:
}

Akhmad Jufriadi $^{1}$, Sukir Maryanto ${ }^{2}$, Adi Susilo ${ }^{2}$, B. Heri Purwanto ${ }^{3}$, M.Hendrasto ${ }^{4}$

\begin{abstract}
ABSTRAK: Aktivitas Gunung Ijen pada bulan Desember 2011 sampai dengan Maret 2012 menarik untuk dikaji karena aktivitas selama bulan tersebut mengalami perubahan status dari kondisi normal menjadi waspada kemudian meningkat menjadi siaga. Tujuan penelitian ini untuk mengetahui karakteristik gempa vulkanik (tipe A dan tipe B) dan tremor harmonik serta melakukan identifikasi kantong magma dan proses internal Gunung Ijen terkait dengan seismisitasnya. Analisa data dilakukan pada data rekaman sesimik dari gempa vulkanik (tipe A dan tipe B) dan tremor harmonik yang didapatkan dari 3 stasiun seismik yaitu Ijen (Ijen), Terowongan Ijen (TRWI) dan Kawah Utara Ijen (KWUI). Sinyal diseleksi berdasarkan waveform dan dianalisis spektralnya untuk mendapatkan kandungan frekuensinya. Analisis hiposenter dilakukan untuk mengetahui kedalaman gempa-gempa vulkanik yang digunakan sebagai dasar identifikasi kantong magma dan proses internal Gunung Ijen. Berdasarkan analisa terhadap data rekaman sinyal seismik didapatkan karakteristik gempa vulkanik dalam (VA) memiliki ciri sinyal dengan amplitude berkisar 5-46 mm, lama gempa berkisar 6-45 detik, kandungan frekuensi berkisar $3,4 \mathrm{~Hz}$ dan kedalaman sumber gempa berkisar $2.500-4.000$ meter dibawah Kawah Ijen. Gempa Vulkanik Dangkal (VB) memiliki ciri sinyal dengan amplitude berkisar 3-46 mm, lama gempa berkisar 5-25 detik, kandungan frekuensi berkisar 2,6 $\mathrm{Hz}$ dan kedalaman sumber gempa berkisar 0 - 2.500 meter dibawah Kawah Ijen. Untuk Tremor vulkanik kandungan frekuensinya berkisar $0,83 \mathrm{~Hz}$, amplitude berkisar $0,5-45 \mathrm{~mm}$ dan sumber berada di bawah kawah. Aktivitas Gempa Vulkanik Gunung Ijen mengalami peningkatan tinggi ditandai dengan peningkatan gempa vulkanik dalam (VA) dan gempa vulkanik dangkal (VB) diikuti oleh tremor harmonik serta peningkatan energi gempa vulkanik yang terkai dengan proses internal yang merupakan proses pergerakan magma dari dalam bumi menuju permukaan disebabkan oleh adanya kegiatan tektonik disekitar gunung yang menyebabkan adanya suplai magma dari kantong magma dalam yang diperkirakan berada pada kedalaman lebih dari 4000 meter dibawah permukaan laut.
\end{abstract}

Kata Kunci : Gunung Ijen, hiposenter, proses internal

\begin{abstract}
Ijen Volcano activities in December 2011 until March 2012 is interesting to study because of the activity during it has a change in the status of the activities from normal level be advisory then increased to watch levels. The purpose of this study to investigate the characteristics of volcanic earthquakes (A-type and B-type) and harmonic tremors and also predicting the internal process of Ijen Volcano associated with seismicity. Analysis of volcanic earthquakes (A-type and Btype) and harmonic tremors has been done used three seismic stations are Ijen (Ijen), Terowongan Ijen (TRWI) dan Kawah Utara Ijen (KWUI). Signals are selected based on the waveform and analyzed to obtain spectral frequency. Hypocenter analysis used to determine the depth of the earthquake. We find thah characteristics of volcanic earthquakes has an amplitude 2-43 mm, duration 10-37 seconds, frequency about $3.4 \mathrm{~Hz}$ for A-type volcanic earthquake and B-type volcanic earthquake has an amplitude 2-43 mm, duration 10-37 seconds, and frequency about $2.6 \mathrm{~Hz}$. Distribution of sorce earthquake position is located at a depth of 0-2500 meters below the crater for B-type volcanic earthquake, 2000-2500 meters below the crater for A-type volcanic earthquake and 5000-50000 meters below sea level to Local Tectonic Earthquake. Volcanic earthquake activites of Ijen Volcano increased with volcanic earthquakes increasing followed by harmonic tremor and also increased of volcanic earthquakes energy. That is about internal process that more caused by displacement the
\end{abstract}

\footnotetext{
1 Program Pasca Sarjana Jurusan Fisika, FMIPA, Universitas Brawijaya (email:akhmadjufriadi@yahoo.co.id)

2 Jurusan Fisika, Fakultas MIPA, Universitas Brawijaya

${ }^{3}$ Pusat Pemantauan Gunung Api Ijen

${ }^{4}$ Pusat Vulkanologi Mitigasi Bencana Geologi
} 
fault due to increased magma activity in magma chamber at a depth of more than 4000 meters below sea level

Key word: Ijen volcano, hypocenter, internal process

\section{PENDAHULUAN}

Gunungapi Ijen yang terletak di ujung timur Pulau Jawa termasuk salah satu gunungapi aktif yang terletak pada zona subduksi antara Eurasia dan Lempeng IndoAustralia [1]. Letak geografis puncaknya $8^{\circ} 03^{\prime} 30^{\prime}$ ' Lintang Selatan dan $114^{\circ} 14^{\prime} 30^{\prime}$ ' Bujur Timur, dengan ketinggian tepi kawah sebesar $2386 \mathrm{~m}$ dpl dan danau kawah $2145 \mathrm{~m}$ dpl.Gunung dengan tipe strato ini secara administratif masuk dalam wilayah Kabupaten Banyuwangi dan Bondowoso Propinsi Jawa Timur [2].Mengacu pada pengalaman dan catatan sejarah pembentukan gunungapi ini pada masa lampau, Kawah Ijen memiliki potensi menghasilkan lahar letusan dan potensi ancaman bahaya erupsi sangat besar. Jumlah populasi yang sangat padat di kawasan rawan bencana Kawah Ijen dan jumlah wisatawan yang cukup banyak menjadi permasalahan yang sangat penting dalam mitigasi bencana Gunungapi Ijen.Untuk mengurangi dampak negatif dari keberadaan Gunungapi Ijen maka diperlukan pemantauan terhadap segala aktivitasnya. Metode yang digunakan dalam penelitian ini adalah dengan metode seismik. Hal ini disebabkan adanya peningkatan aktifitas kegempaan di bawah gunungapi sebelum terjadinya erupsi, karena magma dan gas gunungapi harus terlebih dahulu mendorong ke permukaan melalui rekahan dan lorong-lorong. Ketika magma dan gas vulkanik berpindah akan menyebabkan retakan hingga pecahnya batuan. Retakan atau pecahnya batuan ini akan menjadi sumber getaran. Sebagaimana penelitian [3]yang telah berhasil mengidentivikasi karakteristik Gunungapi Ijen berdasarkan aktivitas kegempaannya atau dari hasil analisis sinyal seismik yaitu bahwa Gunungapi Ijen secara umum didominasi oleh kemunculan gempa vulkanik tipe B (VB), tektonik jauh, dan gempa hembusan. Jumlah kejadian gempa vulkanik tipe B (VB) yang muncul di Gunungapi Ijen berkisar antara 1 sampai 16 kali kejadian per hari. Gempa vulkanik tersebut mempunyai amplitudo maksimum peak to peak berkisar antara 2$43 \mathrm{~mm}$, lama gempa antara 10-37,5 detik. Jumlah kejadian gempa vulkanik tipe A (VA) perharinya tidak sebanyak vulkanik tipe B (VB), sejak tahun 2005 berkisar antara 1-5 kejadian per hari.Secara lebih lanjut dengan menganalisis sinyal seimik akan didapatkan keterkaitan antara sinyak seismik yang satu dengan yang lain sehingga dapat diteliti seperti apa proses internal yang terjadi pada Gunungapi Ijen dengan begitu akan dikenali bagaimana karakteristik Gunungapi Ijen secara lebih detai yang memiliki tipe letusan freatik sehingga nantinya juga akan dapat digunakan sebagai rujukan untuk memahami proses internal yang terjadi pada gunungapi lain dengan karakteristik letusan yang sama.

Pada analisis karakteristik ini, pertama yang dilakukan adalah menganalisis bahwa event terpilih dari semua stasiun diduga berasal dari sumber yang sama dengan membandingkan pola waveform, spektral ataupun spektrumnya, seperti Gambar 1. 


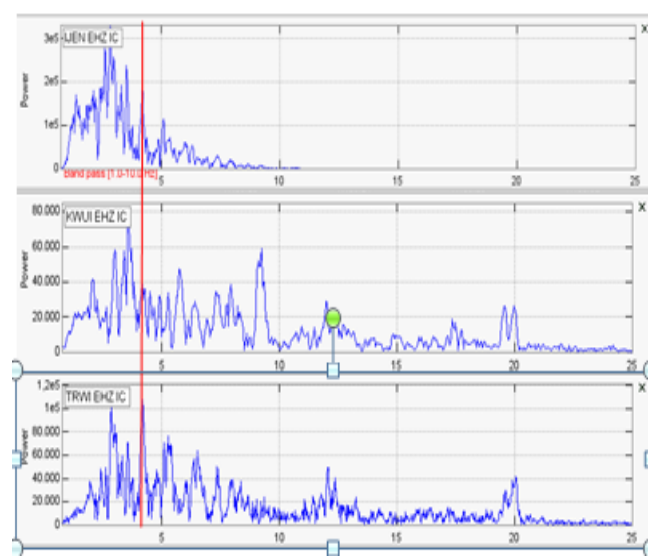

Gambar 1.Kemiripan spektral event 20111201025723

Dari Gambar 1 diatas, ketiga spektral terlihat memiliki pola spektral yang sama. Sehingga bisa dinyatakan bahwa sinyal seismik yang terekam oleh ketiga stasiun berasal dari sumber yang sama. Data rekaman seismik yang terbukti berasal dari sumberer yang sama kemudian dianalisis berdasarkan waveform dengan menggunakan software swarm untuk mengetahui berapakahwaktu tiba gelombang $P$, waktu tiba gelombang $S$, amplitudo,frekuensi dominan, spektrum dan energinya. Seperti tampak pada Gambar 2.

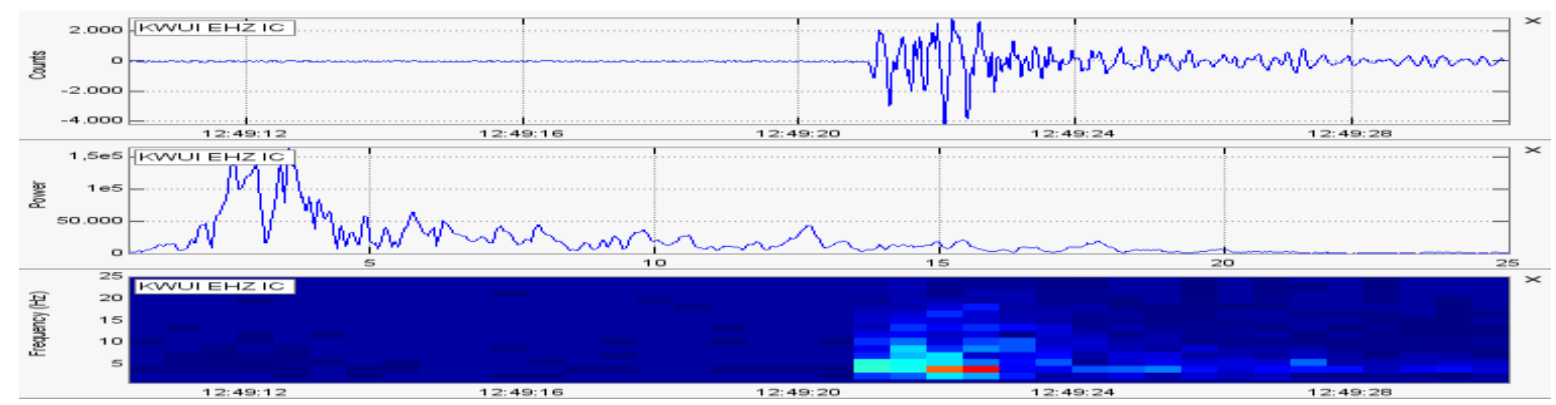

Gambar 2. Kenampakan sinyal, Spektral dan Spektrum Gempa Vulkanik

Penentuan posisi sumber gempa menyangkut pada 2 hal penting, yaitu posisi sumber pada kedalaman tertentu, yang sering disebut sebagai hiposenter, dan posisi di permukaan, yang tegak lurus dengan posisi hiposenter, yang sering disebut sebagai episenter. Metode penentuannya adalah dengan menganalisa beda waktu tiba gelombang $\mathrm{P}$ dan $\mathrm{S}$ antar masing-masing stasiun. Sesuai dengan persamaan berikut:

$$
\begin{array}{ll}
\left(X_{0}-X_{1}\right)^{2}+\left(Y_{0}-Y_{1}\right)^{2}+\left(Z_{0}-Z_{1}\right)^{2}=\left(t_{i}-t_{0}\right)^{2} V p^{2} \\
\left(t_{i}-t_{0}\right) V p=(S-P)_{i} k & \text { dengan }: i=1,2,3, \text { dan } 4 \text { ( stasiun ke- } i),
\end{array}
$$

$(X, Y, Z)_{0}=$ koordinat sumber gempa yang tidak diketahui,$(X, Y, Z) I=$ koordinat stasiun seismograph, $k=$ koefisien jarak yang tidak diketahui. $t_{i}=$ waktu tiba gelombang $P, t_{0}=$ saat terjadinya gempa yang tidak diketahui.Konstanta jarak $(k)$ merupakan konstanta Omori, yang digunakan dalam perhitungan hiposenter, dirumuskan sebagai berikut :

$$
k=\frac{V_{p} x V_{s}}{V_{p}-V_{s}}
$$

Dengan cara matematis ini, sebelumnya harus ditentukan terlebih dulu koordinat masing-masing stasiun dan dianggap semua stasiun tersebut terletak pada satu bidang 
datar. Untuk memudahkan perhitungan dan menghindari kesalahan yang selalu timbul, pada waktu akan dilakukan pengamatan dipilih dulu stasiun seismik yang hampir sama ketinggiannya atau bila mungkin yang terdapat pada ketinggian yang sama. Bila hal ini tidak mungkin, dapat diambil ketinggian rata-rata dan dari ketinggian tersebut kedalaman gempa mulai dihitung. Untuk memudahkan penjelasan, diumpamakan koordinat titik sumber adalah $S$ yaitu $X i, Y i, Z i$. Dan koordinat stasiun diumpamakan titik $H$ yaitu $X, Y, Z$. Dengan kedua koordinat tersebut, dapat dihitung panjang garis $S H$ atau $D$, yaitu :

$$
\begin{aligned}
& S H^{2}=(Y-Y i)^{2}+\left(X-X_{i}\right)^{2} \\
& D^{2}=S H^{2}+(Z-Z i)^{2} \\
& D^{2}=(X-X i)^{2}+(Y-Y i)^{2}+(Z-Z i)^{2}
\end{aligned}
$$

Analisa dengan cara diatas memerlukan ketelitian pembacaan beda waktu tiba antara gelombang $P$ dan $S$, atau lebih dikenal dengan istilah $(S-P)$. Sehingga akan didapatkan posisi hiposenter yang akurat. Dimana posisi hiposenter ini akan mempengaruhi bagaimana analisa terhadap pergerakan magma dari masing-masing tipe gempa vulkanik sebagai dasar untuk mengetahui bagaimana proses internal yang terjadi di Gunungapi Ijen.

\section{HASIL DAN PEMBAHASAN}

\section{Karakteristik dan Aktivitas Gempa Vulkanik Gunungapi Ijen}

Berdasarkan laporan pengamatan Gunung Ijen pada rentang tahun 2011 sampai dengan tahun 2012, gempa vulkanik (tipe-A, tipe-B) dan tremor vulkanik gunung Ijen mengalami fluktuasi jumlah kejadian. Peningkatan aktivitas mulai teramati sejak pertengahan Oktober 20011 yang diawali dengan kejadian gempa tektonik lokal.Seperti yang terlihat pada Gambar 2. Kejadian gempa tektonik lokal mengalami peningkatan mulai tanggal 21-24 Oktober 2011 mencapai rata-rata 3 kejadian gempa tiap harinya. Kejadian tersebut kemudian diikuti meningkatnya kejadian gempa vulkanik.Peningkatan jumlah dan energi gempa vulkanik telah teramati sejak pertengahan Oktober 2011 yang ditandai dengan terjadinya gempa tektonik lokal.Gambar 3 menunjukkan peningkatan aktivitas kegempaan Gunung Ijen yang tinggi ditandai oleh peningkatan gempa vulkanik yang diikuti oleh Tremor Harmonik sejak 15 Desember 2011. Tanggal17 dan 18 Desember 2011 terjadi peningkatan yang cukup tajam pada kejadian gempa vulkanik yaitu 49 Gempa Vulkanik Tipe-A dan 102 Gempa Vulkanik Tipe-B. Peningkatan jumlah gempa vulkanik diikuti oleh peningkatan energi gempa vulkanik pada 17 dan 18 Desember 2011 yang mencapai 4,21 x $10^{14}$ dan $2.1 \times 10^{15}$ erg/hari, yang dapat dilihat pada Gambar 4 . Sedangkan peningkatan aktivitas kegempaan Gunung Ijen yang ditandai dengan peningkatan gempa vulkanik diikuti oleh Tremor Harmonik sejak tanggal 15 Desember 2011 meningkatkan status Gunung Ijen dari NORMAL menjadi WASPADA. Kemudian meningkatnya energi vulkanik yang tinggi pada tanggal 17 - 18 Desember 2011 menjadikan Gunung Ijen dinaikkan statusnya menjadi SIAGA tampak pada Gambar 5. Pada tanggal 8 Februari 2012 status kegiatan Gunung Ijen diturunkan dari SIAGA menjadi WASPADA, karena terjadi penurunan aktivitas kegempaan. Gempa vulkanik mulai terekam lagi secara intensif sejak awal Maret 2012 seperti pada Gambar 5, sehingga pada tangga 12 Maret 2012 status kegiatan Gunung Ijen dinaikkan menjadi SIAGA 
kembali.Peningkatan jumlah aktifitas gempa vulkanik (tipe-A dan tipe-B), Gempa Hembusan dan tremor vulkanik (Gambar 5) mulai terjadi pada tanggal 12 Maret 2012. Tremor dengan amplitudo lebih dari $30 \mathrm{~mm}$ yang tidak terekam menunjukkan adanya tekanan yang dilepaskan. Dari gambar tersebut tampak bahwa awal peningkatan ditandai oleh meningkatnya energi Gempa Vulkanik, dan Tremor yang kemudian disusul oleh peningkatan energi gempa Low Frekuensi serta energi tremor harmonik beramplitudo kurang dari $30 \mathrm{~mm}$ dan energi terlepaskan oleh Tremor Harmonik beramplitudo lebih dari $30 \mathrm{~mm}$.Sejak 13 Maret 2012 terjadi peningkatan energi vulkanik, Hembusan, dan Tremor (Gambar 5) akan tetapi Tremor dengan amplitude $\geq 30 \mathrm{~mm}$ tidak terekam. Tremor dengan amplitude $\geq 30 \mathrm{~mm}$ diplot terpisah dengan asumsi bahwa tremor tersebut merupakan manifestasi dari pelepasan tekanan. Gambar 5 memperlihatkan bahwa awal peningkatan ditandai oleh meningkatnya energi Gempa Vulkanik, Tremor yang kemudian disusul oleh peningkatan energi tremor harmonik beramplitude kurang dari $30 \mathrm{~mm}$ dan terlepaskannya tekanan oleh Tremor Harmonik beramplitude lebih dari $30 \mathrm{~mm}$.
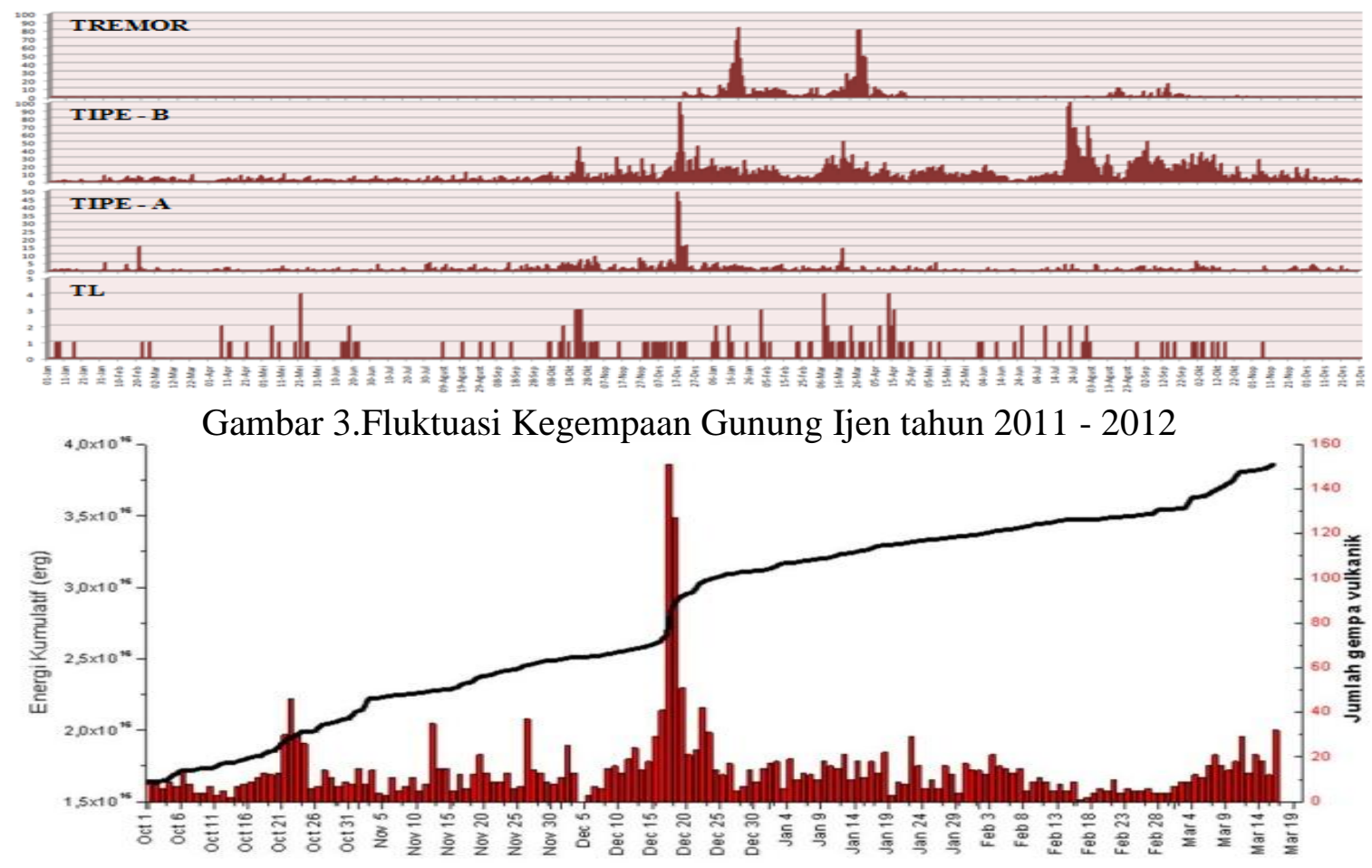

Gambar 4.Grafik Jumlah dan Energi Kumulatif Gempa Vulkanik

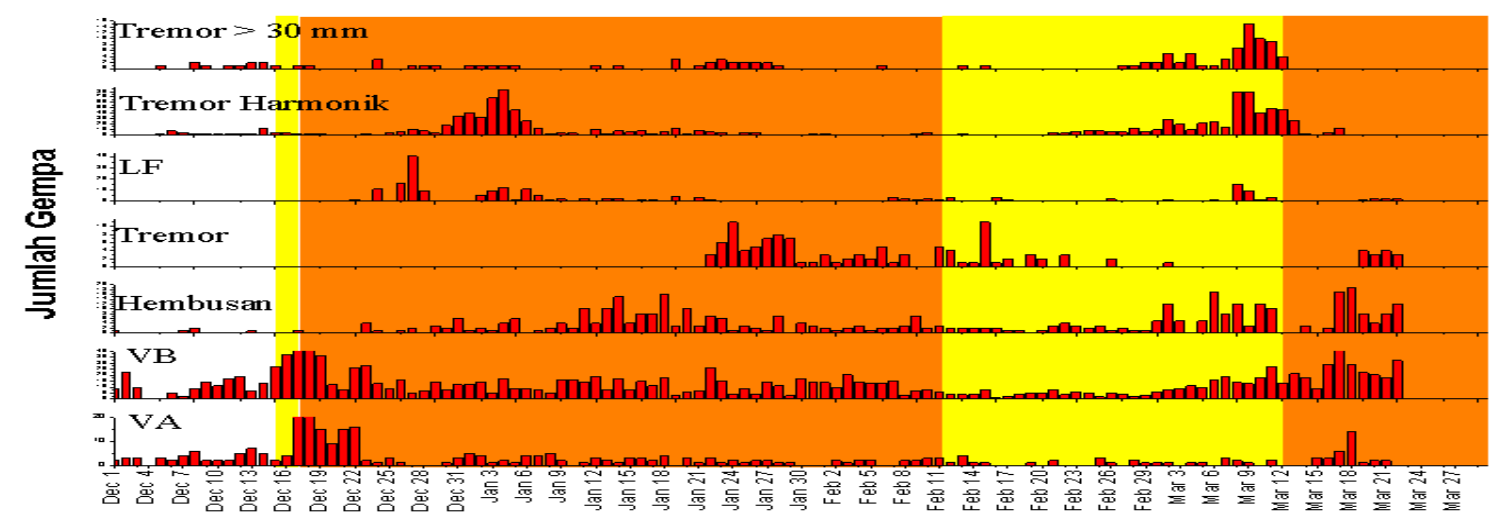

Gambar 5. Grafik kegempaan Gunung Ijen, Desember 2011 - Maret 2012 


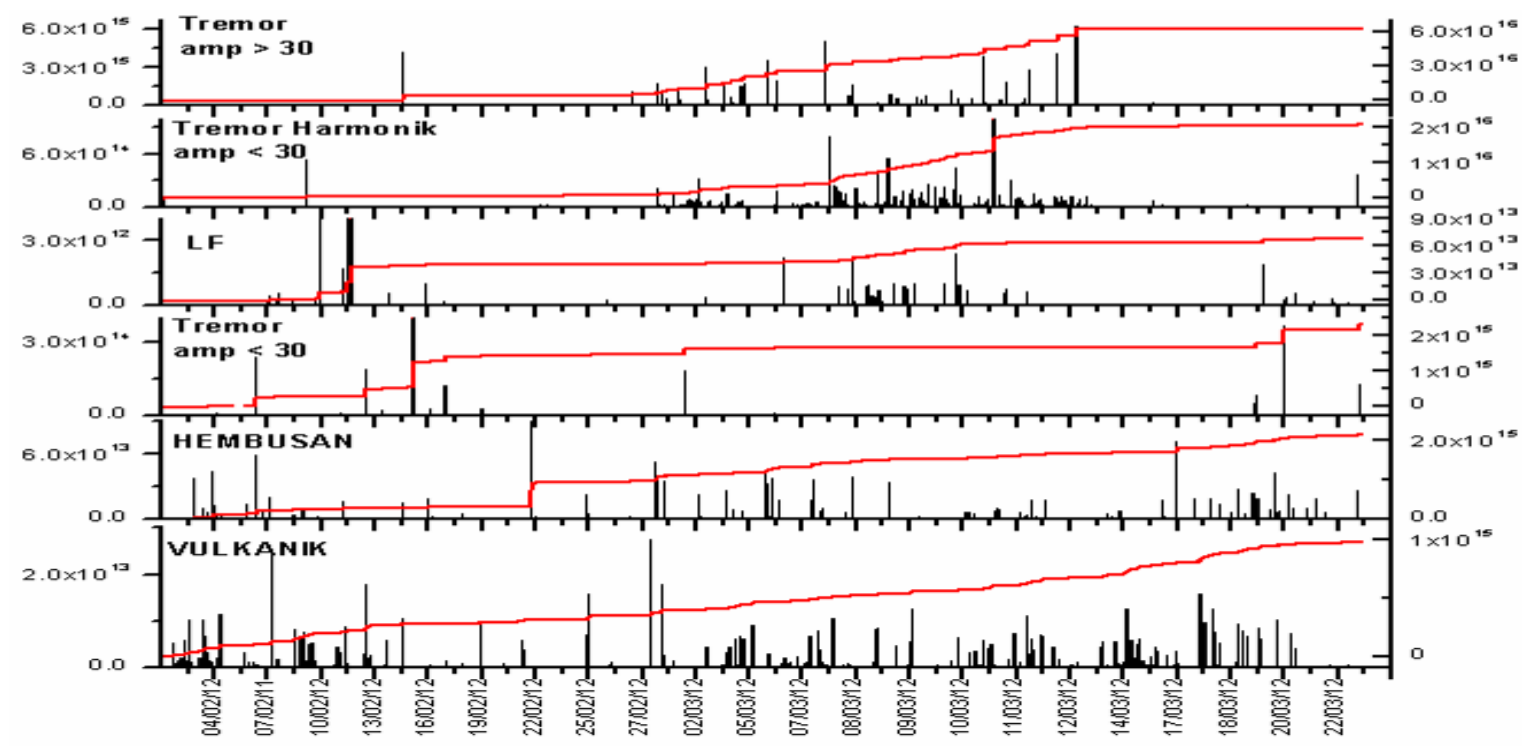

Gambar 6. Kesetaraan Energi tiap Event Gempa Gunung Ijen

Bulan Februari - Maret 2012

Pada Gambar 6, Sejak 13 Maret 2012 terjadi peningkatan energi vulkanik, Hembusan, dan Tremor akan tetapi Tremor dengan amplitude $\geq 30 \mathrm{~mm}$ tidak terekam. Kondisi ini mirip dengan awal Februari dimana peningkatan energi gempa tidak disertai dengan terekamnya Tremor beramplituda $\geq 30 \mathrm{~mm}$. Tremor beramplituda $\geq 30 \mathrm{~mm}$ terekam kemudian pada 15 Februari 2012 dan sebelumnya merekam Tremor Harmonik dengan energi yang cukup besar pada 10 Februari 2012 dengan enegi $5.31 \times 10^{14}$ erg. Tanggal 23 Maret 2012 terekam Tremor Harmonik dengan amplitude $5 \mathrm{~mm}$ dan durasi 3 jam 39 menit, energi $3.63 \times 10^{14} \mathrm{erg}$, merupakan Tremor Harmonik yang paling lama terekam sejak krisis Desember 2011.Berdasarkan pengamatan yang telah dilakukan secara kontinyu di Gunung Ijen, maka gempa vulkanik (Tipe A, Tipe B) dan Tremor Vulkanik dapat dikenali dengan mudah dari waveform nya. Waveform gempa yang telah dijelaskan sebelumnya menjadi dasar untuk melakukan seleksi data. Analisis spektral gempa vulkanik tipe A menunjukkan secara umum kandungan frekuensinya berkisar 3,4 $\mathrm{Hz}$ dan untuk gempa vulkanik tipe B berkisar 2,6 Hz. Hal ini sesuai dengan karakteristik gempa vulkanik yang dinyatakan oleh Iyan Mulyana pada tahun 2005dalam[3]. Adanya perubahan kejadian gempa yang terjadi ternyata diiringi oleh perubahan visual dan kimia fisis air danau Kawah Ijen. Hal ini terjadi disebabkan karena adanya kontak langsung ataupun tidak langsung antara air kawah dengan magma. Bahkan adanya kontak tersebut akan menimbulkan uap yang bertekanan tinggi yang menyebabkan terjadinya letusan freatik.Dari pengamatan visual pada tanggal 17 Desember 2011 dapat disimpulkan bahwa Kawah Ijen mengalami peningkatan dengan adanya perubahan warna air danau kawah, jika dibandingkan dengan pengamatan pada tanggal 14 Desember 2011 saat kondisi normal.Pada tanggal 17 Desember 2011 tampak warna air danau kawah putih berbuih dan berbunyi kemericik, uap air danau kawah putih tipis merata diseluruh permukaan danau.Selain itu juga tampak adanya bualan air ditengah kawah dengan diameter kurang lebih 5 meter.Perubahan visual tersebut menunjukkan bahwa pada saat kejadian telah terjadi peningkatan aktivitas kegempaan. 


\section{Sebaran Hiposenter dan Episenter Terkait Proses Internal}

Hasil analisis posisi sumber gempa yang dilakukan dengan menggunakan data hasil rekaman tiga buah seismometer memperlihatkan adanya migrasi magma menuju permukan.Dari sebaran episenter seperti pada Gambar 13 tersebut tampak bahwa posisi sumber gempa vulkanik dalam (VA) dan vulkanik dangkal (VB) memusat disekitar kawah dengan jarak berkisar $2 \mathrm{~km}$ dan dominan pada arah tenggara dan timur laut.Sedangkan untuk gempa tektonik lokal berada disekitar gunung ijen dengan jarak berkisar $2-10 \mathrm{~km}$ dari kawah ijen pada arah tenggara dan timur laut.Peningkatan aktivitas kegempaan Gunung Ijen yang ditandai dengan peningkatan gempa vulkanik diikuti oleh tremor vulkanik pada tanggal 15 Desember 2011.

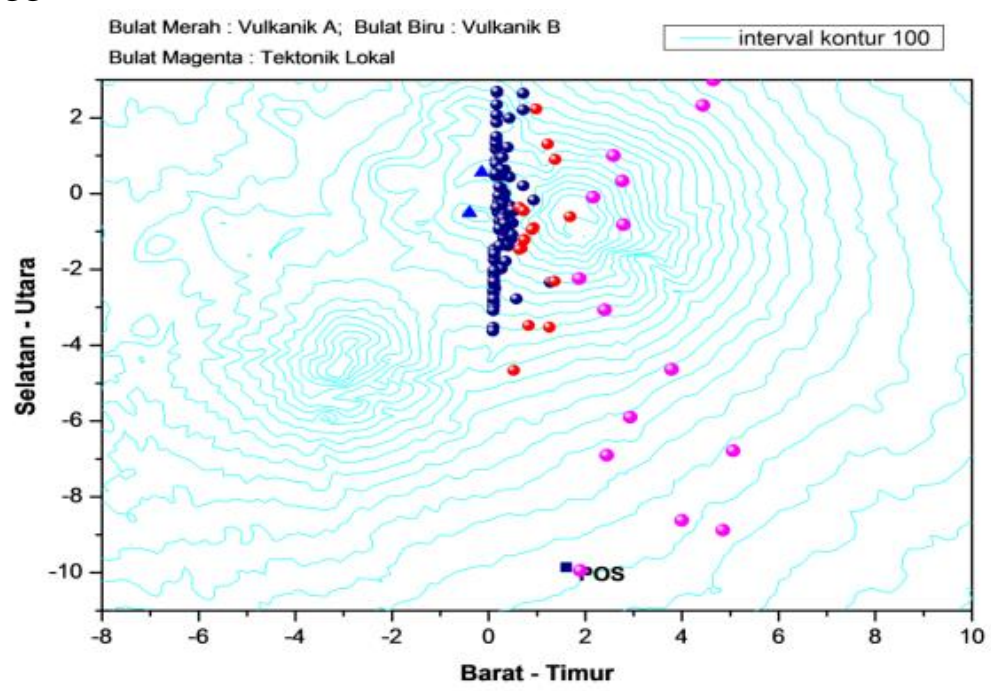

Gambar 8. Episenter gempa vulkanik (tipe A dan tipe B) dan tektonik lokal

Peningkatan tersebut diduga dipicu oleh terjadinya gempa tektonik lokal akibat kegiatan struktur di sekitar Gunung Ijen.Adanya gempa tektonik lokal tersebut memicu terjadinya peningkatan aktivitas magma sehingga terjadi pergeseran patahan yang mengakibatkan terjadinya gempa vulkanik dalam (A). Hal ini sesuai dengan yang dikemukakan oleh Shick, 1981 dalam[4]Dari pola distribusi posisi hiposenter gempa vulkanik dalam (VA) maupun vulkanik dangkal (VB), dapat dilihat perkembangan migrasi magma yang merupakan salah satu penyebab terjadinya gempa vulkanik. Dari Gambar 9 tampak bahwa posisi sumber gempa berada pada kedalaman sekitar 5.000-50.000 meter dibawah permukaan laut untuk gempa tektonik lokal, kedalaman 2.000-6.500 meter di bawah Kawah Ijen untuk gempa vulkanik dalam dan 0-2.500 meter di bawah Kawah Ijen untuk gempa vulkanik dangkal. Peningkatan aktivitas magma mulai tampak dari munculnya gempa vulkanik dalam (VA), kemudian aktivitas magma tersebut terus naik bermigrasi menuju permukaan yang menyebabkan terjadinya gempa vulkanik dangkal.Selain itu juga kalau diperhatikan pada Gambar 9, maka aktivitas magma yang ditandai dengan terjadinya gempa vulkanik tersebut bermigrasi dari sekitar kawah ijen dengan jarak episenter sekitar $2 \mathrm{~km}$ dari Kawah Ijen pada arah selatan, tenggara, timur, dan timur laut menuju ke pusat kegiatan Kawah Ijen yang diduga berada pada titik paling dalam kawah tersebut. Pergerakan magma yang ditandai dengan meningkatnya gempa vulkanik tersebut kemudian juga diikuti oleh terjadinya tremor harmonik. 


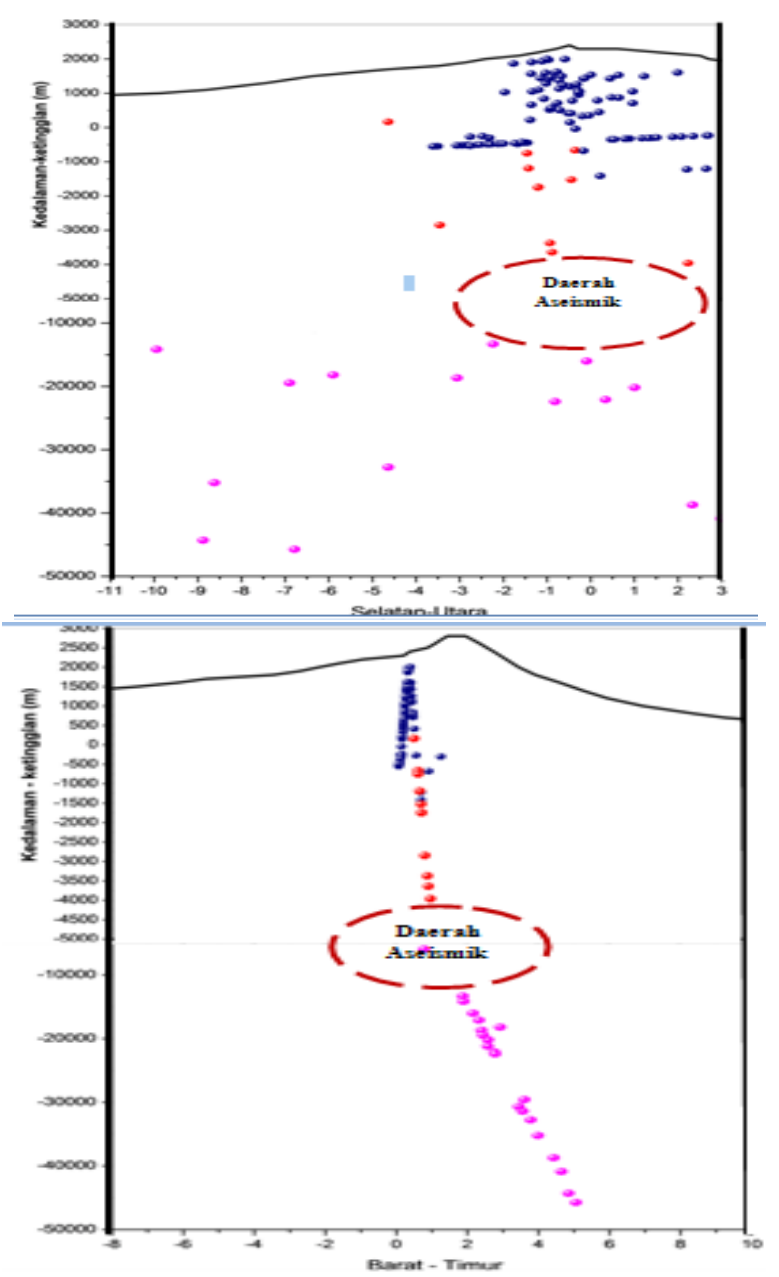

Gambar 9. Hiposenter Gempa Vulkanik

Dari pola sebaran posisi hiposenter gempa maka dapat diduga bahwa daerah aseismik berada pada kedalaman lebih dari 4000 meter dibawah permukaan laut, yang diindikasikan sebagai kantung magma. Kantung magma inilah yang berperan terhada terjadinga gempa vulkanik, baik gempa vulkanik dalam (VA) maupun gempa vulkanik dangkal (VB).Proses internal yang berhubungan dengan terjadinya migrasi magma juga pernah diteliti pada Gunung Semeru. Gunung ini memiliki karakter yang berbeda dengan Gunung Ijen.Dari sifat materialnya Gunung Semeru merupakan tipe gunung andesitik dengan letusan bersifat vulkanian dan strombolian, sedang untuk Gunung Ijen merupakan tipe andesitik - basaltik dan letusannya bersifat freatik.Mengacu pada distribusi posisi sumber gempa dan geologi strukturnya, [5] mengamati bahwa pada Gunung semeru yang memiliki posisi episenter jauh dari pusat kawah (lebih dari $8 \mathrm{~km}$ keatas) mengindikasikan bahwa gempa tidak hanya bersumber dari sekitar pusat conduit saja, melainkan lebih meluas kedaerah sisi tubuh gunung.Hal ini berbeda dengan Gunung Ijen yang memiliki posisi episenter gempa vulkanik berada disekitar kawah yang menunjukkan bahwa gempa bersumber dari pusat conduit.

\section{KESIMPULAN}

Berdasarkan analisis data seismik pada tahun 2011 - 2012 dan data pendukung lainnya, maka didapatkan kesimpulan sebagai berikut : 
1. Karakteristik gempa vulkanik dilihat dari waveform nya memiliki ciri sinyal dengan amplitude berkisar 5 - $46 \mathrm{~mm}$, lama gempa berkisar 6 - 45 detik, kandungan frekuensi berkisar 3,4 Hz untuk Gempa Vulkanik Dalam (VA) dan untuk Gempa Vulkanik Dangkal (VB) sinyal memiliki ciri amplitude berkisar $3-46 \mathrm{~mm}$, lama gempa berkisar 5 - 25 detik, kandungan frekuensi berkisar 2,6 Hz.

2. Sebaran posisi sumber gempa berada pada kedalaman berkisar $0-2.500$ meter dibawah Kawah Ijen untuk Gempa Vulkanik Dangkal (VB), 2.000 - 2.500 meter dibawah Kawah Ijen untuk Gempa Vulkanik Dalam (VA) dan 5.000 - 50.000 meter dibawah permukaan laut untuk Gempa Tektonik Lokal. Kemudian untuk episenter gempa vulkanik (VA dan VB) memusat disekitar kawah dengan jarak berkisar $2 \mathrm{~km}$ dan dominan pada arah tenggara dan timur laut. Sedangkan untuk gempa tektonik lokal berada disekitar gunung ijen dengan jarak berkisar 2-10 km dari kawah ijen pada arah tenggara dan timur laut.Didapatkan pula bahwa daerah aseismik berada pada kedalaman lebih dari 4000 meter dibawah permukaan laut, yang diindikasikan sebagai kantung magma

3. Aktivitas Gempa Vulkanik Gunung Ijen mengalami peningkatan tinggi ditandai dengan peningkatan gempa vulkanik dalam (VA) dan gempa vulkanik dangkal (VB) diikuti oleh tremor harmonik serta peningkatan energi gempa vulkanik yang semua terkait dengan proses internal yang berhubungan dengan terjadinya migrasi magma lebih disebabkan oleh adanya pergeseran patahan yang memicu terjadinya peningkatan aktivitas magma yang dibuktikan dengan terjadinya gempa tektonik lokal sebelum terjadinya gempa vulkanik.

\section{DAFTAR PUSTAKA}

[1] Sumarti, S., Bergen, M. V., Bogaard, T., Sukarnen dan Purwanto, H.B., 2006. Pemantauan Jangka Panjang Kawah Ijen (1922 - 2002) Parameter Fisis : Level Dan Temperatur. Pusat Vulkanologi Dan Mitigasi Bencana Geologi, Bandung.

[2] Kusumdinata, Bergen, M. V., Bogaard, T., Sukarnen dan Zaeni., 2006. Geokimia Danau Kawah Ijen. Pusat Vulkanologi Dan Mitigasi Bencana Geologi, Bandung.

[3] Hendrasto, M., 2006. Pemantauan Seismisitas Gunung Ijen, Pusat Vulkanologi Dan Mitigasi Bencana Geologi, Bandung.

[4] Maryanto, S. 1999. Analysis of Seismic Signal of Mt Semeru (East Java, March 1st21st, 1988) In Order to Determine It's Source and Eruption Mechanism, Tesis, Universitas Gajahmada, Jogjakarta.

[5] Andryana, K., 2011. Mekanisme Fokus Gempa Vulkanik Tipe A Gunung Semeru, Jawa Timur - Indonesia, Tesis, Universitas Brawijaya, Malang. 